\title{
Cloning of the Enomycin Structural Gene from Streptomyces mauvecolor and Production of Recombinant Enomycin in Escherichia coli
}

\author{
Saori Takeuchi, Tomoichiro OKa, Nobuo Sakata, Kayoko S-Tuchiya, \\ Hidemi Hayashi and Makoto Hori \\ Showa College of Pharmaceutical Sciences, \\ Machida, Tokyo 194, Japan \\ (Received for publication June 24, 1996)
}

\begin{abstract}
A genomic DNA library from the enomycin (ENM) producer, Streptomyces mauvecolor, was screened for the ENM structural gene (enm) by use of a segment of the phenomycin gene ( $\mathrm{phm}$ ) as the probe, and a plasmid, pEN1, was constructed. By primer-walking along the insert, a 573 bp DNA sequence that contain an ORF corresponding to preENM was determined. The deduced amino acid composition of ENM was close to that previously reported (MizUNo, S.; K. NitTA \& H. UMEZAwA: Mode of action of enomycin, an antitumor antibiotic of high molecular weight. I. Inhibition of protein synthesis. J. Biochem. 61: 373 381, 1967). The producer cells expressed enm during an ENM-productive fermentation. An enm-expression plasmid, pENE 1, was constructed, with which $E$. coli $\mathrm{AD} 202$ was transformed. The transformant produced a fusion protein consisting of glutathione-S-transferase (GST) and ENM. The genetically engineered ENM (rENM) inhibited the growth of Hela cells in vitro. Comparison of the base sequence spanning enm with that spanning phm showed that the structural genes were conserved more extensively than were the flanking regions, though the genes were unlikely to be essential to the lives of the producers.
\end{abstract}

Enomycin (ENM) and phenomycin (PHM) are polypeptide antitumor antibiotics isolated by $\mathrm{H}$. UMEZAWA's group ${ }^{1,2)}$. Based on the amino acid sequence of $\mathrm{PHM}^{3)}$, we previously cloned the PHM structural gene $(\mathrm{phm})$ from the producer strain, Streptoverticillium baldaccii and found that PHM was produced as prePHM that had a leader peptide of 45 amino acid residues ahead of the $\mathrm{N}$-terminus ${ }^{4}$ ). Structural similarity between PHM and ENM was expected because of the similar amino acid compositions ${ }^{5}$, though the amino acid sequence of ENM remained unknown.

In the present study, we cloned the ENM structural gene (enm) from Streptomyces mauvecolor A390-P4 (ENM producer) using a partial sequence of $\mathrm{phm}$ as the probe, constructed an expression system of enm in E. coli, and confirmed the biological activity of the genetically engineered ENM.

\section{Materials and Methods}

Materials

E. coli AD2026,7), a protease-negative strain, was kindly provided by T. SAITO, Chiba University. Vector pGEX-KT ${ }^{8)}$ was kindly provided by $J_{A C K}$ E. Dixon, University of Michigan Medical School. GlutathioneSepharose 4B and thrombin were purchased from Pharmacia (Uppsala, Sweden). Restriction enzymes were purchased from TOYOBO (Tokyo, Japan) and
TAKARA (Tokyo, Japan) and sequencing kits were from TAKARA, United States Biochemicals (Cleveland, U.S.A.) and Pharmacia. Streptomyces mauvecolor A390-P4, producer of ENM, was obtained from the Institute of Microbial Chemistry.

\section{Shotgun Cloning and Sequencing of enm}

Total DNA from the ENM producer was digested with BamHI, etc., at 10 units enzyme/ $\mu \mathrm{g}$ DNA, electrophoresed in a $0.7 \%$ agarose gel, Southern transferred ${ }^{9)}$, and hybridized with a ${ }^{32} \mathrm{P}$-labeled DNA probe corresponding to the amino acid sequence from $\mathrm{Arg}^{14}$ to $\mathrm{Ala}^{72}$ of PHM. BamHI digests of $4.8 \mathrm{~Kb}$ were extracted from the gel, ligated to pUC118 and the products were used to transform E. coli DH5a. Colonies positive to the same probe were selected. From an isolate, a plasmid was extracted, purified and identified as pEN1 (Fig. 2). Primer walking along $\mathrm{pEN} 1$ was initiated with a 24 -mer primer that corresponded to a partial sequence of $\mathrm{phm}$.

Northern Blot Analysis of enm-mRNA

The BamHI insert in pEN1 was amplified by PCR, and the product was ${ }^{32} \mathrm{P}$-labeled by the random primer method $\left(10^{9} \mathrm{cpm} / \mu \mathrm{g}\right)^{10)}$ and used as the probe. Total RNA was extracted from ENM producer cells ( $2 \mathrm{~g}$ wet weight) that had been withdrawn from a productive fermentation on day 4 or 6 . The RNA samples, $20 \mu \mathrm{g}$ each, were electrophoresed in a $1.2 \%$ formaldehyde gel, Northern blotted, and hybridized with the above (prehybridization and hybridization at $42^{\circ} \mathrm{C}$, final washing in $0.2 \times \mathrm{SSC}$ at $45^{\circ} \mathrm{C}$ for 30 minutes) prior to 
autoradiography.

Expression of enm in E. coli

pEN1 was double-digested with $S m a I$ and $S p h \mathrm{I}$, the products were electrophoresed, and $1.15 \mathrm{~Kb}$ fragments including enm were extracted from the gel. Using the fragment as a template, enm (not including the segment for the leader peptide codons) was amplified by PCR with Bam 5' primer (5'-CGGTGGGATCCAACCCGAAGACG-3') and Eco $3^{\prime}$ primer (5'-CGAGGCGAATTCGGCCTCACCAG- $3^{\prime}$ ), in repeating 30 cycles of heating at $100^{\circ} \mathrm{C}$ for 40 seconds and at $63^{\circ} \mathrm{C}$ for 90 seconds, and the reaction was finished by heating at $63^{\circ} \mathrm{C}$ for 5 minutes. The products were double-digested with $B a m \mathrm{HI}$ and $E c o$ RI and electrophoresed in a $2 \%$ agarose gel. The $297 \mathrm{bp}$ fragment, extracted from the gel, was ligated to vector pGEX-KT and submitted to transformation of $E$. coli DH $5 \alpha$. Among ampicillin resistant colonies, a transformant that included pENE1 was cloned. The insert and the short flanking regions were sequenced to confirm that enm was ligated behind the GST gene in the correct reading frame. $E$. coli AD202 was transformed with pENE1 and a transformant was selected, cloned and named AD202/pENE1. The clone was cultured with shaking at $37^{\circ} \mathrm{C}$ in $100 \mathrm{ml} \times 10$ flasks of L-broth containing ampicillin at $50 \mu \mathrm{g} / \mathrm{ml}$, until the turbidity $(660 \mathrm{~nm})$ reached 0.8 . IPTG was then added to $0.1 \mathrm{~mm}$ final concentration and incubation with shaking was continued for 2.5 hours. Cells were harvested by centrifugation at $4^{\circ} \mathrm{C}$ (all lysis and fractionation procedures were also carried out at $4^{\circ} \mathrm{C}$, except when otherwise described), washed with PBS, suspended in $25 \mathrm{ml}$ of PBS, and disrupted in a Branson Sonifier Model 350 (Duty Cycle at 25\%, Output Control at 1, Pulsed). The homogenate was centrifuged at $6,600 \times g$ for 10

Fig. 1. Genomic southern blot analysis of enm.

(A) Ethidium bromide staining, (B) autoradiogram.

(A)

1. 2. 3. 4. 5 .

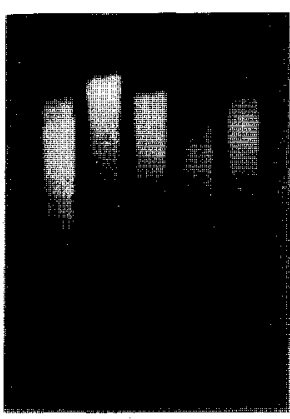

Total DNA from the enomycin producer, Streptomyces mauvecolor was digested with restriction enzymes and probed with phm. The arrow indicates the $4.8 \mathrm{~Kb}$ Bam HI band. Enzymes used were 1. BamHI, 2. EcoRI, 3. PstI, 4. $S a c \mathrm{I}$, and 5. SphI minutes. To the resulting supernatant of about $25 \mathrm{ml}$, was added $0.4 \mathrm{ml}$ of $50 \%(\mathrm{v} / \mathrm{v})$ slurry of Glutathione Sepharose $4 \mathrm{~B}$, prepared as recomended by the manufacturer (Pharmacia). The mixture was shaken for 40 minutes at a room temperature and centrifuged. The pelleted resin that adsorbed the fusion protein was washed five times with $2.5 \mathrm{ml}$ of PBS, incubated for 16 hours at a room temperature with 200- $\mu$ l of PBS containing 10 units of thrombin to release ENM, and centrifuged. The supernatant was combined with the washings of the resin $(2 \times 200 \mu 1$ of PBS) to obtain approximately $600 \mu \mathrm{l}$ of an ENM solution. The purification steps were monitored by SDS-polyacrylamide gel electrophoresis (See Legend to Fig. 5). Protein concentrations were determined by the Bradford $\operatorname{method}^{11)}$.

\section{Results and Discussion}

\section{Cloning of Enomycin Gene}

Total DNA from the ENM producer was digested with various restriction enzymes, electrophoresed and Southern hybridized with the DNA probe that corresponded to a partial amino acid sequence of $\mathrm{PHM}$, i.e., $\operatorname{Arg}^{14}$ to $\mathrm{Ala}^{72}$. The shortest hybridization target observed was an BamHI fragment of about $4.8 \mathrm{~Kb}$, as shown in Fig. 1. Therefore, DNA was extracted from this region of the gel and ligated to pUC118. With the products, E. coli DH5 $\alpha$ was transformed. Out of nine candidate colonies, two were confirmed to include the desired plasmid, pEN1 (Fig. 2), that included the $4.8 \mathrm{~Kb}$ insert. The DNA sequence ( $573 \mathrm{bp}$ ) that included enm was determined, as shown in Fig. 3. By analogy with the PHM precursor protein ${ }^{4)}$, the leader peptide of ENM, from Met $^{-46}$ to $\mathrm{Ala}^{-1}$, was deduced, which showed several characteristics of leader peptides of streptomyces ${ }^{12)}$. ENM was thought to be produced as a precursor protein of 135 amino acid residues (preENM) that would be split into

Fig. 2. Restriction map of pEN 1 .

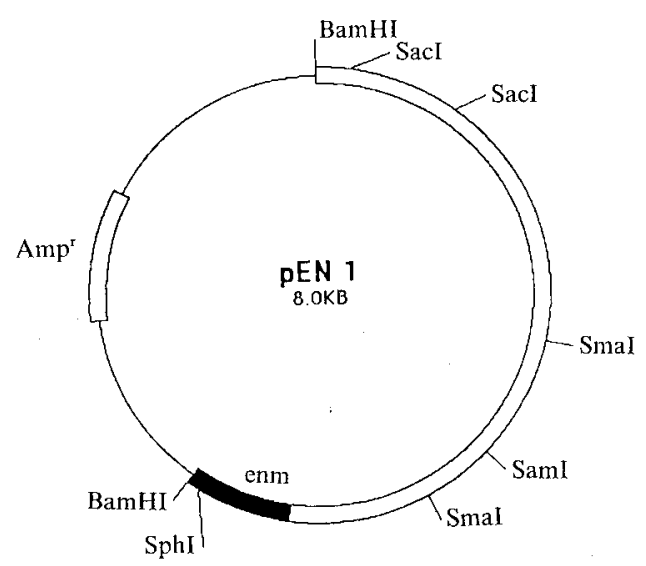


Fig. 3. Nucleotide sequence of enm.

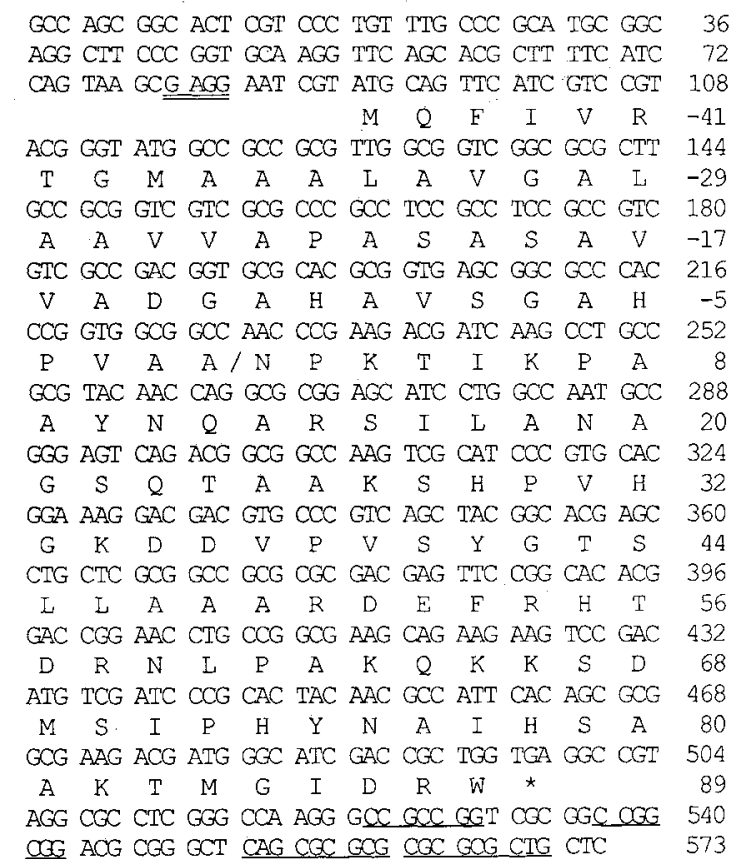

The slash indicates the splitting site between the leader peptide and ENM. The putative ribosome binding site is double-underlined. The potential transcription terminator is underlined. The nucleotide sequence data of enm will appear in the DDBJ, EMBL and GeneBank Nucleotide Sequence Databases with the accession number D85170.

the leader peptide and ENM. Throughout the structural gene for preENM, the total GC content was $70 \%$, while that for the $3 \mathrm{rd}$ codon position was $93 \%$, consistent with data for other structural genes of Streptomyces. The deduced amino acid composition of ENM agreed with the composition reported ${ }^{5)}$ except for the presence of a previously-undetected Phe residue (encoded by TTC, codon 54). A possible ribosome-binding sequence (GAGG) was found 6 residues upstream of the initiator ATG, while there were two inverted repeat sequences commence at residues 24 and 54 downstream of the terminator TGA, respectively, possibly acting as transcription terminators. Northern blot analysis showed that this gene was transcribed into an about 630 nucleotides long RNA on the 4th day of ENM-producing fermentation. The RNA seemed long enough to code preENM that was 135 amino acids long.

\section{Production of Recombinant Enomycin}

The DNA fragment $(297 \mathrm{bp})$ that included the ENM-encoding sequence but not the leader peptide codons was amplified by PCR and the product was ligated to an expression vector pGEX-KT to give pENE1 (Fig. 4), with which E. coli AD202 was transformed and the

Fig. 4. Production of glutathione-S-transferase (GST)-enomycin (ENM) fusion protein.

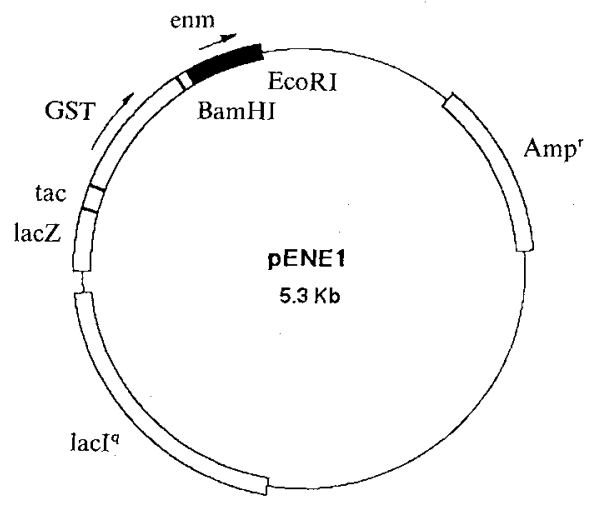

GST-ENM
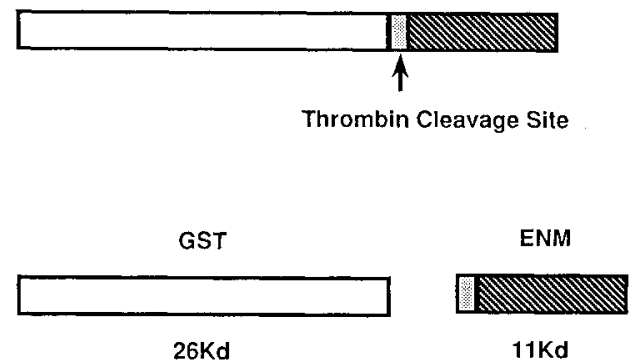

Fig. 5. SDS-polyacrylamide gel analysis of purified rENM

$\begin{array}{lllll}1 & 2 & 3 & 4 & 5\end{array}$

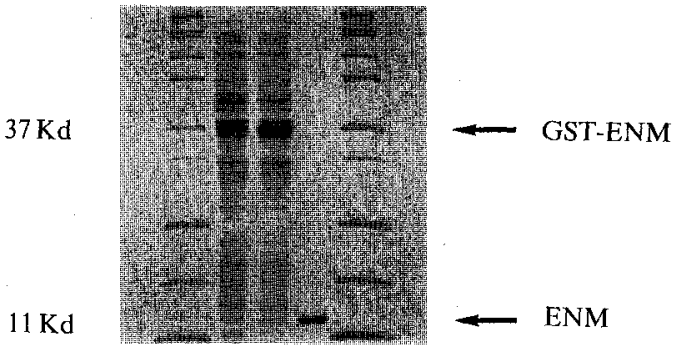

A $10 \mu \mathrm{l}$ sample was mixed with $3 \mu \mathrm{l}$ of a buffer containing $62.5 \mathrm{~mm}$ Tris- $\mathrm{HCl} \mathrm{pH} 7.0,10 \%$ glycerol, $2 \%$ SDS, $720 \mathrm{~mm}$ $\beta$-mercaptoethanol, $0.00125 \%$ Bromophenol Blue, heated on a boiling water bath for 5 minutes, and electrophoresed in a $14 \%$ SDS-polyacrylamide minigel (TEFCO) at $20 \mathrm{~mA}$ for 80 minutes. The gel was immersed successively in $100 \mathrm{ml}$ of a staining solution $(0.2 \%$ Coomassie Brilliant Blue R250 in $20 \%(\mathrm{~V} / \mathrm{V})$ acetic acid/methanol) at $65^{\circ} \mathrm{C}$ for 10 minutes and in $150 \mathrm{ml}$ of a destaining solution $(50 \%$ methanol, $37.5 \%$ acetic acid) overnight. Lane I: Protein size markers. Lane 2: Total proteins from uninduced cells. Lane 3: Total proteins from induced cells. Lane 4: Purified rENM after thrombin cleavage. Lane 5: Protein size markers.

clone was named $E$. coli AD202/pENE1. The clone was grown in L-broth, induced using IPTG, and the fusion protein GST-ENM was isolated from cell lysates by adsorption to glutathione-Sepharose 4B. ENM was released from the affinity resin on digestion with 
Fig. 6. Comparison between amino acid sequences for enomycin and phenomycin.

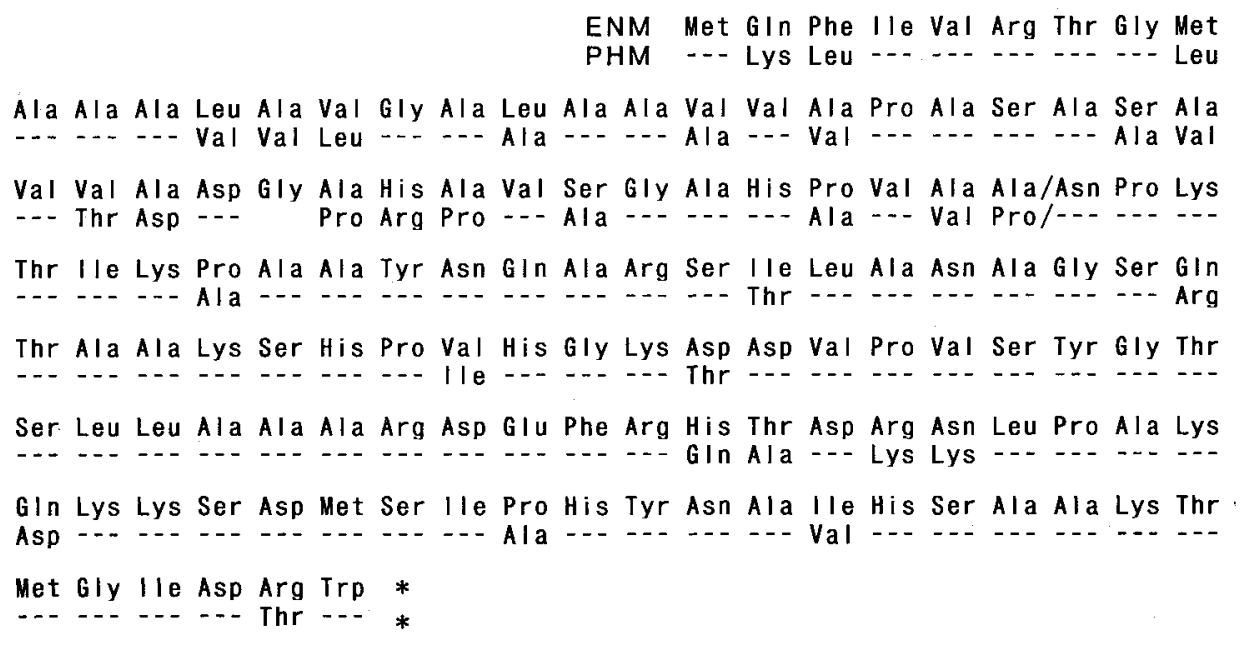

Dashed amino acid residues are identical between the two proteins.

thrombin. The isolation procedure was monitored by electrophoretic analysis of proteins, as shown in Fig. 5. From a $1,000 \mathrm{ml}$ culture of the clone, $3 \mathrm{mg}$ of purified ENM was obtained. The productivity could possibly be improved if the codons of enm were replaced with those of $E$. coli type. The genetically engineered ENM, having an extra Gly-Ser dipeptide on the $N$-terminal, inhibited in vitro the growth of Hela cells by $50 \%$ at $2.2 \mu \mathrm{g} / \mathrm{ml}$.

\section{Why ENM and PHM are Produced}

As shown in Fig. 6, the amino acid sequences of ENM and PHM shared $84 \%$ homology in their mature protein regions. The conserved amino acid residues should include important ones for the biological activity of the proteins, i.e., inhibition of eukaryotic protein synthesis. The leader peptide regions showed 59\% homology, apparently lower than that for the mature proteins. We suggest that the producer strains have been under evolutionary pressure to produce and secrete proteins with such biological activity. Comparison between the DNA sequences supports this idea more clearly. Similarity between the segments "outside the structure gene", between "leader peptide codons" and between "mature protein codons" were 44\% (74/165 bases), 71\% (98/138 bases) and $86 \%$ (232/270 bases), respectively. In the natural environment for the producer strains, i.e., in the soil, what eukaryote is the natural enemy to be killed with ENM or PHM?
Acknowledgments

The authors are grateful to Drs. TAKASHI SAITo, JACK E. Dixon and MaKoto KaWAGUCHI for their helpful comments. The technical assistance of Miss M. HosodA is gratefully acknowledged.

\section{References}

1) Suhara, Y.; M. Ishizuka, H. Naganawa, M. Hori, M. Suzuki, Y. OKami, T. TakeUchi \& H. UmeZawa: Studies on enomycin, a new antitumor substance. J. Antibiotics Ser. A 16: $107 \sim 108,1963$

2) Nakamura, S.; T. Yajima, M. Hamada, T. Nishimura, M. IshizuKa, T. TAKeUChI, N. TANaKa \& H. UMEZAWA: A new antitumor antibiotic, phenomycin. J. Antibiotics Ser. A 20: $210 \sim 216,1967$

3) Muramatsu, R.; S. Abe, H. Hayashi, K. Yamaguchi, K. Jinda, K. SaKano, Y. InOUYE \& S. NaKamura: Complete amino acid sequence of phenomycin, an antitumor polypeptide antibiotic. J. Antibiotics 44: 1222 1227, 1991

4) Sakata, N.; T. Oka, S. Ikeno, M. Hori, K. Yamaguchi, Y. INOUYE \& S. NAKAMURA: Nucleotide sequence of the phenomycin gene from Streptoverticillium baldacci Ma564-C1. J. Antibiotics 47: 370 371, 1994

5) TANaka, N.: Phenomycin and enomycin. In Antibiotics, Vol. V/Part 1. Ed., F. E. HAHN, pp. 235 242, Springer-Verlag, Berlin, 1979

6) AkiYama, Y. \& K. Iто: SecY protein, a membraneembedded secretion factor of $E$. coli, is cleaved by the OmpT protease in vitro. Biochem. Biophys. Res. Commun. 167: 711 715, 1990

7) Nakano, H.; T. Yamazaki, M. Ikeda, H. Masai, S. Miyatake \& T. Saito: Purification of glutathione S-transferase fusion protein as a non-degraded form by using a proteinase-negative $E$. coli strain, AD202. Nucleic Acids Res. 22: 543 544, 1994 
8) Hakes, D. J. \& J. E. Dixon: New vectors for high level expression of recombinant proteins in bacteria. Anal. Biochem. 202: 293 298, 1992

9) Southern, E. M.: Detection of specific sequences among DNA fragments separated by gel electrophoresis. J. Mol. Biol. 98: 503 517, 1975

10) Feinberg, A. P. \& B. Vogelstein: A technique for radiolabeling DNA restriction endonuclease fragments to high specific activity. Anal. Biochem. 132: 6 13, 1983
11) Bradford, M. M.: A rapid and sensitive method for the quantitation of microgram quantities of protein utilizing the principle of protein dye binding. Anal. Biochem. 72: $248 \sim 254,1976$

12) Mansouri, K. \& W. PiePersberg: Genetics of streptomycin production in Streptomyces griseus: Nucleotide sequence of five genes, strFGHIK, including a phosphatase gene. Mol. Gen. Genet. 228: 459 469, 1991 